\title{
PRMT1 Gene
}

National Cancer Institute

\section{Source}

National Cancer Institute. PRMT1 Gene. NCI Thesaurus. Code C134685.

This gene plays a role in the regulation of transcription via the methylation of histones and chromatin. 